\title{
Pruritus and severe iron deficiency in polycythaemia vera
}

\author{
HATEM H SALEM, MARTIN B VAN DER WEYDEN, IAN F YOUNG, JAMES S WILEY
}

\begin{abstract}
Six patients diagnosed as having polycythaemia vera had severe pruritus that persisted despite adequate haematological control. Iron supplementation was given when iron deficiency was noted in all six patients. The pruritus began to improve two to 10 days after the start of treatment and had completely disappeared after two to three weeks. In three patients the iron treatment was stopped because of unacceptably high haemoglobin concentrations; the pruritus recurred.

Since chronic iron treatment may result in increases in red cell mass indiscriminate use of iron in patients with polycythaemia vera and pruritus is not advocated. Nevertheless, in patients with severe symptoms and evidence of iron deficiency treatment with iron, continuing for two to three weeks after the symptoms have abated, may be beneficial.
\end{abstract}

\section{Introduction}

Pruritus of varying severity is a common and characteristic symptom of patients with polycythaemia vera. ${ }^{1}$ In some of these patients pruritus continues to be recalcitrant to conventional antipruritic measures despite reduction of the red cell mass. ${ }^{2}$ We report here on six such patients in whom administration of oral iron alone resulted in complete resolution of pruritus, suggesting that severe iron deficiency may contribute to this symptom in some patients with polycythaemia vera.

Monash University Department of Medicine, Alfred Hospital, Prahran, Victoria, Australia

HATEM H SALEM, MRCP, lecturer

MARTIN B VAN DER WEYDEN, MD, clinical associate professor

Department of Haematology, Austin Hospital, Heidelberg, Victoria, Australia

IAN F YOUNG, MB, BS, registrar

JAMES S WILEY, MD, director

\section{Patients, methods, and results}

The six patients reported on here (two men, four women; age range 58-76 years) satisfied suggested diagnostic criteria for polycythaemia vera, ${ }^{3}$ and all exhibited varying degrees of hepatosplenomegaly. All haematological procedures were performed according to standard methods. ${ }^{4}$ Mean blood variables at presentation were haemoglobin concentration $18.2 \mathrm{~g} / \mathrm{dl}$ (range 17.1-19.5), leucocyte count $19.0 \times 10^{9} / 1$ (range 12.5-26), and platelet count $485 \times 10^{9} / 1$ (range 180-900). The red cell mass as measured by the chromium-51 technique ${ }^{4}$ ranged from 40 to $66 \mathrm{ml} / \mathrm{kg}$ (normal 26-35). Bone-marrow aspirates showed panmyelosis with an absence of stainable iron. The increased red cell mass was managed with regular venesection in all patients. In addition one patient received busulphan and two phosphorus-32.

Despite adequate haematological control (packed cell volume below 0.55 ) pruritus persisted and was the dominant symptom in four of the patients. At various times four of the patients received oral cyproheptadine alone and three oral cyproheptadine in combination with cimetidine with no effect. At the time that pruritus was the leading symptom iron deficiency was noted in all six patients (table). Because of this iron supplementation was given as ferrous fumarate $150 \mathrm{mg}$ thrice daily in one patient, ferrous sulphate (Ferro-Gradumet) $300 \mathrm{mg}$ daily in three, and ferrous gluconate $300 \mathrm{mg}$ thrice daily in two. In all patients this was associated with considerable amelioration of the pruritus: improvement was noted two to 10 days after the start of treatment, with complete disappearance of symptoms after two to three weeks.

In two patients the rising haemoglobin concentrations after iron treatment were controlled by concomitant administration of busulphan. In three other patients iron treatment was stopped because of unacceptably raised haemoglobin concentrations that were difficult to control and required vigorous venesection. In two of these patients

Iron state before iron treatment in the six patients with pruritus and polycythaemia vera

\begin{tabular}{|c|c|c|c|c|c|c|c|}
\hline & \multirow{2}{*}{$\begin{array}{c}\text { Normal } \\
\text { range }\end{array}$} & \multicolumn{6}{|c|}{ Case No } \\
\hline & & 1 & 2 & 3 & 4 & 5 & 6 \\
\hline Packed cell volume & $0.4-0.54$ & $0 \cdot 48$ & 0.55 & 0.42 & 0.48 & 0.52 & 0.56 \\
\hline $\begin{array}{l}\text { volume }(\mathrm{f}) \\
\text { Iron }(\mu \mathrm{mol} / \mathrm{l}) \\
\text { Transferrin }(\mathrm{g} / \mathrm{l}) \\
\text { Ferritin }(\mu \mathrm{g} / \mathrm{l}) \\
\text { Bone-marrow iron }\end{array}$ & $\begin{array}{c}76-96 \\
7-27 \\
2 \cdot 1-3 \cdot 6 \\
20-200\end{array}$ & $\begin{array}{c}69 \\
4 \\
3 \cdot 8 \\
11 \\
\text { Absent }\end{array}$ & $\begin{array}{r}68 \\
3 \\
3 \cdot 9 \\
\text { ND } \\
\text { ND }\end{array}$ & $\begin{array}{c}65 \\
6 \\
4 \cdot 5 \\
9 \\
\text { Absent }\end{array}$ & $\begin{array}{c}67 \\
10 \\
3 \cdot 8 \\
10 \\
\text { Absent }\end{array}$ & $\begin{array}{c}74 \\
5 \\
5 \cdot 1 \\
11 \\
\text { Absent }\end{array}$ & $\begin{array}{c}66 \\
8 \\
3 \cdot 5 \\
\text { ND } \\
\text { Absent }\end{array}$ \\
\hline
\end{tabular}

$\mathrm{ND}=$ Not done

Conversion: SI to traditional units-Iron: $1 \mu \mathrm{mol} / 1 \approx 5.6 \mu \mathrm{g} / 100 \mathrm{ml}$. 
pruritus recurred within two and six weeks and was associated with reduced mean corpuscular volume $(<75 \mathrm{fl})$ and serum ferritin concentrations $(<20 \mu \mathrm{g} / \mathrm{l})$. Iron treatment was restarted and continued for only two to four weeks after the pruritus had cleared.

\section{Discussion}

Pruritus occurs in up to $60 \%$ of patients with polycythaemia vera. ${ }^{1}$ Classically it is aggravated by hot baths, and in some patients it interferes substantially with either sleep or daytime activities during summer. There appears to be no real correlation between the severity of polycythaemia vera and the itching. Histamine has long been regarded as a major mediator of this symptom, ${ }^{5}$ but the failure of histamine antagonists to control pruritus in most patients, together with the presence of hyperhistaminaemia in the absence of pruritus in other disorders, ${ }^{5}$ suggest that other factors play a part. Iron deficiency has been cited as a cause of generalised pruritus ${ }^{6}{ }^{7} ;$ and some degree of iron deficiency, shown by absent marrow iron, is almost universal in polycythaemia vera. ${ }^{3}$ Surprisingly, however, iron deficiency is not mentioned in any report as a possible cause for the pruritus in this disease.

In two previous reports examining the association of iron deficiency and pruritus ${ }^{8}{ }^{9}$ a favourable effect of iron treatment on the pruritus of two patients with polycythaemia vera was noted. These reports, however, did not give pertinent haematological details.

All six patients reported on here had documented polycythaemia vera with severe pruritus. During this period of heightened pruritus severe iron deficiency was present in all cases, and with oral iron treatment this abated over two to three weeks. In two of three patients requiring venesection because of a progressive rise in packed cell volume pruritus returned and values of haematological variables indicated iron deficiency. Treatment with iron resulted in an amelioration of this symptom. Since chronic iron treatment may result in progressive increases in the red cell mass we do not advocate indiscriminate use of iron in all patients with polycythaemia vera and pruritus. Only in those with severe symptoms and evidence for iron deficiency may iron be of help, and our current practice is to continue such treatment for only two to three weeks after the symptom has abated.

This study was supported in part by grants from the National Health and Medical Research Council of Australia.

\section{References}

1 Winkelmann RK, Muller SA. Pruritus. Ann Rev Med 1964;15:53-64.

2 Chanarin I, Szur L. Relief of intractable pruritus in polycythaemia rubra vera with cholestyramine. Br $\mathcal{F}$ Haematol 1975;29:669-70.

3 Berlin NI. Diagnosis and classification of the polycythaemias. Semin Hematol 1975;12:339-51.

4 Dacie JV, Lewis SM, eds. Practical haematology. 5th ed. Edinburgh: Churchill Livingstone, 1975.

${ }^{5}$ Gilbert HS, Warner RRP, Wasserman LR. A study of histamine in myeloproliferative disease. Blood 1966;28:795-806.

6 Sneddon IB, Church RE. Practical dermatology. 2nd ed. London: Edward Arnold, 1971:125.

${ }^{7}$ Rook AJ, Wilkinson DS, Ebling FJG. Textbook of dermatology. 2nd ed. Oxford: Blackwell, 1972:1799.

${ }^{8}$ Sneddon IB, Garretts $M$. The significance of low serum iron levels in the causation of itching. In: Jadassohn W, Schirren CG, eds. Proceedings of XIII international congress of dermatology, Munich. Berlin: Springer, 1968:1061-3.

${ }^{9}$ Vickers CFH. Nutrition and the skin: iron deficiency in dermatology. In : Ledingham JCG, ed. Proceedings of tenth symposium on advanced medicine. London: Royal College of Physicians, 1974:311-5.

(Accepted 24 May 1982)

\title{
Postoperative analgesia with controlled-release morphine sulphate: comparison with intramuscular morphine
}

\author{
D FELL, A CHMIELEWSKI， G SMITH
}

\begin{abstract}
Fifty patients undergoing hysterectomy or cholecystectomy took part in a trial of postoperative analgesia provided by either intramuscular morphine or controlledrelease morphine sulphate tablets orally. Respiratory function and plasma catecholamine concentrations were measured after operation and pain was assessed by using a linear analogue scoring method. Controlledrelease morphine sulphate produced comparable pain relief with that of intramuscular morphine, and depression of respiratory function after operation was similar with the two analgesic regimens. The mean total dose of drug per patient given over $48 \mathrm{~h}$ to patients undergoing
\end{abstract}

Leicester Royal Infirmary, Leicester LE1 5WW

D FELL, FFARCS, senior registrar in anaesthesia

A CHMIELEW SKI, FFARCS, senior registrar in anaesthesia

University Department of Anaesthesia, General Hospital, Leicester LE5 4PW

G SMITH, MD, FFARCS, professor of anaesthesia hysterectomy was $115 \mathrm{mg}$ for morphine sulphate and $\mathbf{5 3}$ mg for morphine. Patients undergoing cholecystectomy received $130 \mathrm{mg}$ morphine sulphate or $76 \mathrm{mg}$ morphine. There was more sedation after operation in those patients undergoing hysterectomy who received morphine sulphate tablets.

Morphine sulphate tablets produced satisfactory postoperative analgesia compared with intramuscular morphine: both regimens were acceptable to the patients.

\section{Introduction}

Relief of postoperative pain is unsatisfactory despite vigorous attempts to apply recently developed analgesics and newer administration techniques. Epidural techniques after operation have become more popular and the administration of opiates in place of local anaesthetic drugs through the epidural catheter has provided some advantages. ${ }^{12}$ In addition, the administration of opiate analgesics by continuous intravenous infusion ${ }^{3}$ or patient-operated demand techniques ${ }^{4}$ has been advocated. These methods are relatively expensive, however, and require close supervision of the patient or the apparatus to monitor side effects or malfunction. Thus, the use of conventional intra- 